\title{
Heat treatment of cream affects the physicochemical properties of sweet buttermilk
}

\author{
Jean-Yves GASSI*, Marie-Hélène FAMELART, Christelle LOPEZ \\ INRA, Agrocampus Rennes, UMR1253, Science et Technologie du Lait et de l'Euf, \\ 65 rue de Saint-Brieuc, 35042 Rennes Cedex, France
}

Received 28 September 2007 - Accepted 19 February 2008

\begin{abstract}
The objective of this work was to investigate the effect of heat treatment of sweet creams on the physicochemical properties of sweet industrial buttermilks. Creams with three different heat treatments: low, medium and high, were churned and the corresponding buttermilks were characterised. Furthermore, buttermilks were renneted and centrifuged to obtain insoluble pellets and supernatants. The physicochemical properties such as the particle size measured by laser light scattering and composition of creams, buttermilks, pellets and supernatants were determined and compared. Buttermilk had a composition close to that of skim milk but it contained more phospholipids (PL): $958( \pm 137) \mathrm{mg} \cdot \mathrm{kg}^{-1}$, compared with $120 \mathrm{mg} \cdot \mathrm{kg}^{-1}$ in milk. The heat treatment induced a significant decrease in soluble protein contents in creams, buttermilks and soluble fractions as well as an increase in the buttermilk PL/fat ratio, and an increase in supernatant protein and total solids. Buttermilk and supernatant particle sizes ranged from 0.03 to $200 \mu \mathrm{m}$, with a maximum at $130 \mathrm{~nm}$, which may correspond to small milk fat globules, phospholipid vesicles or protein aggregates. Fat and PL in buttermilks were recovered in supernatants. The use of buttermilk enzymatic coagulation combined with centrifugation may constitute a means to fractionate milk PL.
\end{abstract}

\section{buttermilk / phospholipid / protein / heat treatment / particle size}

\begin{abstract}
摘要 - 奶油热处理对甜酪乳物理化学性质的影响。本文研究了甜奶油的热处理对工业生 产甜酪乳物理化学性质的影响。低、中、高温热处理的奶油经摚打后生产出相应的酪乳。 经凝乳酶凝乳的酪乳离心后得到了不溶性的颗粒和上清液。采用激光散射法测定颗粒大 小, 并测定和比较了奶油、酪乳、颗粒和上清液的组成。酪乳的组成接近脱脂乳, 但其磷脂 (958 ( \pm 137$\left.) \mathrm{mg} \cdot \mathrm{kg}^{-1}\right)$ 含量高于原奶 $\left(120 \mathrm{mg} \cdot \mathrm{kg}^{-1}\right)$ 。热处理使得奶油、酪乳和可溶性馏分中 可溶性蛋白的含量明显降低, 也就是使酪乳中磷脂 / 脂肪的比率增加和上清液中蛋白及总固 形物含量增加。酪乳和上清液的颗粒大小的范围在 0.03-200 $\mu \mathrm{m}$, 集中分布在 $130 \mathrm{~nm}$, 可能 是由于较小的乳脂肪球、磷脂囊泡或蛋白质的凝聚作用。可以从上清液中回收酪乳的脂肪 和磷脂, 因此, 酪乳经酶凝固并结合离心有可能成为一种从乳中提取磷脂的方法。
\end{abstract}

\section{酪乳 / 磷脂 / 蛋白 / 热处理 / 颗粒大小}

Résumé - Le traitement thermique des crèmes affecte les propriétés physico-chimiques des babeurres doux. L'objectif de ce travail était de caractériser l'effet de l'intensité des traitements thermiques appliqués aux crèmes sur les propriétés physico-chimiques des babeurres doux industriels. Des crèmes ayant subi 3 traitements thermiques différents (faible, moyen et fort) ont été barattées, et les babeurres obtenus ont été caractérisés. De plus, les babeurres ont été coagulés par la présure puis centrifugés afin d'obtenir un culot insoluble et un surnageant. La composition des

*Corresponding author (通讯作者): jean-yves.gassi@ rennes.inra.fr 
crèmes, babeurres, sérums et culots, ainsi que la taille des particules ont été déterminées et comparées. L'augmentation de l'intensité des traitements thermiques conduit à une diminution significative de la concentration en protéines solubles dans les crèmes, babeurres et surnageants, à une augmentation du ratio phospholipides/matière grasse du babeurre, ainsi que de l'extrait sec et de la matière azotée totale des surnageants. Les babeurres avaient des compositions proches de celle du lait écrémé, mais avec une concentration plus importante en phospholipides : $958( \pm 137) \mathrm{mg} \cdot \mathrm{kg}^{-1}$ contre $120 \mathrm{mg} \cdot \mathrm{kg}^{-1}$. Les particules des babeurres et des surnageants avaient un diamètre compris entre 0,03 et $200 \mu \mathrm{m}$ avec un maximum centré sur $130 \mathrm{~nm}$. Ces particules pourraient correspondre à des globules gras de petite taille, des vésicules de phospholipides et/ou des agrégats de protéines. La totalité des lipides contenus dans les babeurres a été retrouvée dans la fraction soluble des surnageants. Techniquement, une coagulation enzymatique du babeurre suivie d'une centrifugation pourrait constituer un moyen de fractionnement des phospholipides.

\section{babeurre / phospholipide / protéine / traitement thermique / taille de particule}

\section{INTRODUCTION}

Buttermilk is the aqueous phase released during cream churning while butter manufacturing. It has a composition close to that of skimmed milk but it also contains specific and interesting components: buttermilk is rich in phospholipids (PL) and proteins from the milk fat globule membrane (MFGM) [33].

In France, the production of 328850 tons of butter in 2006 generated 30300 tons of buttermilk powder intended mainly for animal feeding [4]. In spite of its economic interest, the composition, as well as the physicochemical and functional properties of buttermilk remain poorly known. Moreover, its current outlets are limited and weakly developed, but they could be improved with a better knowledge of both the composition and the properties of buttermilk and a control of the process (mechanical and heat treatments).

During cream churning, the MFGM is broken and its material is mainly found in buttermilk. The MFGM has a composition and a structure in tri-layers which results from the mechanisms of secretion of the MFG [8]. It is mainly made up of polar lipids which are closely associated with various specific proteins among which xanthine oxydase/dehydrogenase, butyrophilin and adipophilin are the most abundant [27]. From 5 to 7 times as many PL in buttermilk as in full-cream milk have been reported $[5,9]$. PL of dairy origin are natural emulsifiers with functional properties [42] that can be used in the food, cosmetic and pharmaceutical industries. Moreover, PL have positive effects on human health [43], in particular by reducing the risk of colon cancer $[23,39,40]$ and intestinal infection $[38,44]$. In the milk industry, buttermilk is used in the formulation of dairy ice cream [35], yoghourt [47] or recombined milk [41]. Addition of buttermilk increases cheese yields by improving water retention in the manufacture of low-fat Cheddar [48] and Mozzarella [34]. The composition and properties of buttermilk render this by-product a potentially very interesting dairy functional ingredient from an economic point of view.

In most of the studies found in the literature, the characteristics of buttermilk are not clearly defined. It is used in the form of commercial powder or liquid from dairy companies, without any further precision. Further, when fresh liquid buttermilk is studied, the cream has often been churned slowly ( 20-30 rpm) for 40-60 $\mathrm{min}$ in a traditional rotary butter churn. However, approximately $90 \%$ of French commercial butter is made by highspeed continuous churning or the NIZO process [22]. Phase inversion takes place very rapidly in the churning cylinder where 
high-speed beaters (1000-2500 rpm) disrupt the MFGM. Most of the buttermilk drains away from the butter granules instantly, which is not the case with slow batch churning [20]. The impact of this processing method may suggest different buttermilk compositions from the literature. Only little work exists on the composition of industrial buttermilk, specifying the effect of its origin (geographical origin, season, heat treatment of the cream, butter technology, etc.) and its technological abilities (study of rennet or acid coagulation). The effect of technological treatments such as heat treatment applied to the cream and the consequences on the buttermilk properties are not known and thus remain to be elucidated. The MFGM particle sizes are analysed from buttermilk powder reconstituted in oil-water emulsion. Some studies focused on the PL content of buttermilk, others on proteins and very few on both. The majority of technological work tackles the subject of buttermilk used in the form of complements in milk enrichment uses prior to cheese-making [31]. There exists no information on the state of coagulum of a cheese-making matrix manufactured with $100 \%$ buttermilk.

The objective of this study was to relate the intensity of the thermal treatment applied to the creams to the chemical composition of the industrial sweet buttermilks. Moreover, we focused on the fat globule size in the creams and on the particle size distribution in buttermilk. The partition of lipids and proteins after renneting of buttermilks was evaluated as a function of heat treatment of the creams.

\section{MATERIALS AND METHODS}

\subsection{Samples}

Creams characterised by different levels of heat treatments and the corresponding buttermilks were provided by the UCLAB dairy company (Landerneau, France). They were prepared as follows:

- On day 0 , raw whole milk was pasteurised at $72{ }^{\circ} \mathrm{C}$ for $15 \mathrm{~s}$ and skimmed at $50{ }^{\circ} \mathrm{C}$ in order to concentrate the milk fat globules in creams at $413( \pm 34) \mathrm{g} \cdot \mathrm{kg}^{-1}$ fat. Then, three different heat treatments were applied to the creams: (i) low heat treatment: $88^{\circ} \mathrm{C}$ for $80 \mathrm{~s}$; (ii) medium heat treatment: $94{ }^{\circ} \mathrm{C}$ for $80 \mathrm{~s}$; and (iii) high heat treatment: $70{ }^{\circ} \mathrm{C}$ for $2 \mathrm{~h}$ then $88^{\circ} \mathrm{C}$ for $30 \mathrm{~s}$ and finally, $94^{\circ} \mathrm{C}$ for $80 \mathrm{~s}$, in three successive steps. Each heat treatment was applied in triplicate. Each day, the three heat treatments were applied to three different creams.

- On day 1, after a physical maturation $\left(\sim 12-13 \mathrm{~h}\right.$ at $\left.10-12{ }^{\circ} \mathrm{C}\right)$ leading to the partial crystallisation of milk fat globules, the sweet creams were churned in a continuous butter-making machine (Contimab, Simon, Cherbourg, France). Each churning operation lasted about $30 \mathrm{~min}$ at a cream flow rate of 10000-12 $000 \mathrm{~L}$ per h. During the phase inversion, butter grains were separated and washed in the draining section with chilled buttermilk, without the addition of water. Butter was not characterised during this study. Buttermilk was collected in the factory after cream churning. Three creams (C-Low, C-Medium and C-High) and the three respective sweet buttermilks (B-Low, B-Medium and B-High) were dispatched each time in isothermal parcels $\left(\sim 10{ }^{\circ} \mathrm{C}\right)$ and received at the Laboratory (INRA-STLO, Rennes, France) within $24 \mathrm{~h}$. This operation was done three times. At reception, $0.2 \mathrm{~g} \cdot \mathrm{kg}^{-1}$ sodium azide was added to the creams and buttermilks, to prevent bacterial growth.

- On day 2, one $\mathrm{kg}$ of buttermilk was weighed in a flask and heated at $40{ }^{\circ} \mathrm{C}$ in a water bath. After $1 \mathrm{~h}$, rennet (Maxiren 180, DSM Food Specialties, Lille, France) was added at $0.012 \mathrm{~mL} \cdot \mathrm{kg}^{-1}$. After $1 \mathrm{~h}$, buttermilk centrifugation was carried out at $20{ }^{\circ} \mathrm{C}$ for $20 \mathrm{~min}$ at $7000 \times g$ (Jouan KR 4i centrifuge, Fisher Bioblock 
Scientific, Ilkirch, France). The insoluble pellet and soluble supernatant were separated, weighed and fraction yields were calculated. The protein recovery coefficient in the insoluble fraction was calculated as follows:

$\begin{aligned} \mathrm{R}= & {\left[\left(\text { Weight }_{\text {insoluble }} \times\right.\right.} \\ & \left.\left.\text { Protein }_{\text {insoluble }}\right) / \text { Protein }_{\text {buttermilk }}\right] \times 100,\end{aligned}$

where Weight insoluble $_{\text {is }}$ the weight of insoluble fraction in $\mathrm{g}$ per $\mathrm{kg}$ of butter-

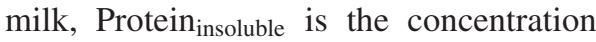
of proteins in $\mathrm{g}$ per $\mathrm{kg}$ of insoluble fraction and Protein buttermilk is the concentration of proteins in $\mathrm{g}$ per $\mathrm{kg}$ of buttermilk. The weight of the insoluble fraction was calculated by the difference between buttermilk and supernatant weights. For each initial heat treatment of cream (Low, Medium and High), 3 independent soluble (S-Low, S-Medium and S-High) and insoluble (I-Low, I-Medium and I-High) fractions were obtained and characterised.

\subsection{Particle size distribution measurements}

The particle size distribution was measured by laser light scattering (Mastersizer 2000, Malvern Instruments, Malvern, UK) with two laser sources, as previously described in detail $[24,29]$. The refractive indexes used were 1.458 and 1.460 for milk fat at 633 and $466 \mathrm{~nm}$, respectively, and 1.33 for water. The samples (about $0.2 \mathrm{~mL}$ ) of cream, buttermilk and supernatant fraction were diluted in $100 \mathrm{~mL}$ of MilliQ water directly in the measurement cell of the apparatus in order to reach $10 \%$ obscuration. The casein micelles were dissociated by adding $1 \mathrm{~mL}$ of $35 \mathrm{mmol} \cdot \mathrm{L}^{-1}$ EDTA/NaOH, pH 7 buffer to the samples, in the apparatus. For the creams, $1 \mathrm{~mL}$ of sodium dodecyl sulphate (SDS, $1 \% \mathrm{p} / \mathrm{v}$ ), an anion detergent, was added in order to dissociate the aggregates of fat globules.
The particle size distribution parameters were calculated by the Mastersizer software: modal diameter $\left(\mathrm{D}_{\text {mod }}\right.$; diameter at the peak maximum of the main population), volume-weighted average diameter, $\mathrm{D}_{43}=\Sigma n_{i} \cdot d_{i}^{4} / \Sigma n_{i} d_{i}^{3}$ (where $n_{i}$ is the number of particles of diameter $d_{i}$ ) and the diameter below which $50 \%\left(\mathrm{D}_{\mathrm{v} 0.5}\right)$ and $90 \%$ $\left(D_{\mathrm{v} 0.9}\right)$ of the particle volume lie.

\subsection{Physicochemical analyses}

All physicochemical analyses were carried out at least twice on fresh products: creams, buttermilks, and soluble and insoluble fractions.

Total solids (TS) were determined after desiccation for $7 \mathrm{~h}$ at $102-105^{\circ} \mathrm{C}$ [11]. Total nitrogen (TN) was determined by the Kjeldahl method [12]. Soluble nitrogen at $\mathrm{pH} 4.6$ (NCN, non-casein nitrogen) and $12 \%(\mathrm{v} / \mathrm{v})$ TCA-soluble nitrogen (NPN, non-protein nitrogen) were determined as described by Gripon et al. [16]. Protein was calculated as TN - NPN, soluble protein by $\mathrm{NCN}-\mathrm{NPN}$ and casein by TN $-\mathrm{NCN}$. Total calcium concentration in buttermilk, and soluble and insoluble fractions was determined by atomic absorption spectrometry (Varian AA 300 equipment, Les Ulis, France) according to Brulé et al. [3]. pH was measured using a 406M6 Ingold electrode (Mettler, Toledo, Viroflay, France) linked to a Hi 9025 pH-meter (Hanna, Humeau, La Chapelle-sur-Erdre, France). The acidity determination in Dornic degrees was carried out by the AFNOR NFV 04-206 method [1].

\subsection{Fat extraction and phospholipid quantification}

Fat content in insoluble fractions was determined using the acid butyrometric method of Van Gulick [14].

Total lipids were extracted from creams by means of hexane-isopropanol $(3: 2, \mathrm{v} / \mathrm{v})$ 
according to Wolff and Fabien's [52] and Wolff and Castera-Rossignol's [51] methods. The milk fat extraction procedure was adapted with a centrifugation step. At room temperature, $2.4 \mathrm{~mL}$ isopropanol (Carlo Erba, Val-de-Reuil, France) were added to $3 \mathrm{~g}$ of cream. The mixture was vortexed. Then $3.6 \mathrm{~mL}$ hexane (Carlo Erba, Valde-Reuil, France) were added. The resulting mixture was vortexed again and centrifuged at $1000 \times g$ at $20{ }^{\circ} \mathrm{C}$ for $5 \mathrm{~min}$ (Heraus cryofuge M7000, Fisher Bioblock Scientific, Ilkirch, France). The upper organic phase was separated through aspiration. To the bottom layer, $6 \mathrm{~mL}$ of $3: 2(\mathrm{v} / \mathrm{v})$ isopropanol-hexane were added, vortexed, centrifuged and the clear upper layer separated. This extraction/purification step was repeated 3 times. The 4 pooled organic fractions were solvent-evaporated under vacuum at $50{ }^{\circ} \mathrm{C}$ until constant weight.

The extraction of total lipids for the determination of the total fat content and phospholipids in high-water content samples, i.e. buttermilks and soluble fractions, was performed after freeze-drying them. Freeze-dried buttermilk and soluble fraction were hydrated with $24 \mathrm{~g}$ of deionised water at $40{ }^{\circ} \mathrm{C}$ for $6 \mathrm{~g}$ of powder and vortexed. One hour after rehydration, the fat extraction protocol was the same as for cream, but with $15 \mathrm{~mL}$ hexane and $10 \mathrm{~mL}$ isopropanol.

The amount of phospholipids in the total fat extracted from creams, buttermilks and soluble supernatant fractions was determined by the method of proportioning of phosphorus (Standards IDF 33C: 1987) [10]. Briefly, the extracted fats were digested with sulphuric acid and hydrogen peroxide. The phosphorus was converted into molybdenum blue with sodium molybdate and ascorbic acid. Phosphorus was estimated colorimetrically after complex formation with molybdate. The optical density was measured at a wavelength of $820 \mathrm{~nm}$. A series of standard solutions containing known quantities of $\mathrm{KH}_{2} \mathrm{PO}_{4}$ was used to construct a curve from which the phosphorus content could be read off. The quantity of phosphorus obtained was multiplied by a conversion factor of 25 to determine the phospholipid content compared with the total lipids of the samples [46].

\subsection{Reverse-Phase High-Performance Liquid Chromatography (RP-HPLC)}

Protein composition of the soluble fractions was determined by RP-HPLC as described in Jean et al. [19]. Briefly, $250 \mathrm{mg}$ of freeze-dried buttermilk were reconstituted and mixed with $10 \mathrm{~g}$ of deionised water. $\mathrm{pH}$ was adjusted to 4.6 with $\mathrm{HCl} 1 \mathrm{~mol} \cdot \mathrm{L}^{-1}$ and then the solution was filtered on Whatman filter paper grade 42 (Fisher Bioblock Scientific, Ilkirch, France). Filtrate was diluted $1 / 2$ in buffer A $(0.106 \%$ v/v trifluoroacetic acid in MilliQ water). Calibration was performed with $\beta$-lactoglobulin $(\beta-\mathrm{Lg})$ (Sigma-Aldrich, Saint-Quentin Fallavier, France) and $\alpha$-lactalbumin ( $\alpha$-La), with from 6 to $25 \mu \mathrm{g}$ injected. The column was an Apex wide-pore ODS column of $25 \mathrm{~cm}$ length, $0.46 \mathrm{~cm}$ inner diameter and $7 \mu \mathrm{m}$ bead diameter (Jones Chromatography, Hengoed, UK). The analysis was performed at $40{ }^{\circ} \mathrm{C}$ on $50 \mu \mathrm{L}$ of sample (loop size) with a gradient of buffer B $(0.106 \%$ $\mathrm{v} / \mathrm{v}$ trifluoroacetic acid in $80 \% \mathrm{v} / \mathrm{v}$ acetonitrile in MilliQ water) increasing from 43 to $100 \%(\mathrm{v} / \mathrm{v})$ in $35.2 \mathrm{~min}$. The flow rate was $1 \mathrm{~mL} \cdot \mathrm{min}^{-1}$ and detection was at $280 \mathrm{~nm}$.

\subsection{Statistical analysis}

We performed a factorial design with one factor: the heat treatment, applied to three different levels: low, medium and high. For each experiment, one heat treatment referred to one different cream. Three independent thermal treatments were applied to creams, meaning 
that $n=3$ for each level of heat treatment. The StatGraphics Plus software (Manugistics, Rockville, USA) was used to perform analysis of variance. A Fisher test was followed by a least square difference procedure by size, to test the significance of result differences. The levels of significance selected were $P \leqslant 0.05(*), P \leqslant 0.01(* *)$ and $P \leqslant 0.001(* * *)$.

\section{RESULTS AND DISCUSSION}

\subsection{Composition of the heat-treated creams and comparison with the corresponding buttermilks}

The compositions of the creams characterised by different levels of heat treatments and the corresponding buttermilks obtained after the butter-making process are presented in Table I.

The average $\mathrm{pH}$ of the creams was $6.78( \pm 0.01)$ and corresponded to that of sweet buttermilk, $6.78( \pm 0.05)$. The acidity of the creams was $10.00{ }^{\circ} \mathrm{D}$ and the average acidity of the buttermilks was $15.13( \pm 0.56){ }^{\circ} \mathrm{D}$. The acidity test measured the concentration of acidic compounds in sweet cream without biological ripening and sweet buttermilk. The higher acidity measured for buttermilks compared with the creams was due to casein, whey protein, phosphate, citrate and carbon dioxide in the aqueous phase. B-High acidity was significantly lower (14.67 ( \pm 0.52$\left.)^{\circ} \mathrm{D}\right)$ than B-Low and B-Medium. This result was correlated with a lower protein content.

The heat-treated creams of increased heat intensity had decreasing protein contents $(P<0.01)$. These lower protein contents could be due to differences in fat contents of creams. Indeed, the protein/non-fat ratio which corresponds to the protein content in the aqueous phase showed no significant differences as a function of the heat treatment.
The protein/non-fat ratio calculated for buttermilks showed significant $(P<0.05)$ differences, with a lower value for the high heat-treated buttermilk (Tab. I). The protein content of the buttermilks resembled that of skim milk ( $\sim 30 \mathrm{~g} \cdot \mathrm{kg}^{-1}$ of protein).

Regarding more particularly the nature of proteins, Table I shows that the casein/protein ratio calculated for the creams and the buttermilks significantly $(P<$ 0.001) increased with the intensity of heat treatment. Denatured whey proteins by heat treatment become insoluble at pH 4.6. Casein content increased because whey proteins are titrated with the casein fraction. Nevertheless, the total protein content in cream significantly decreased from low heat to medium heat and to high heat-treated cream $(18.21,17.46$ and $16.83 \mathrm{~g} \cdot \mathrm{kg}^{-1}$, respectively). So, the differences in casein contents can only be underlined with casein/protein ratios. Moreover, the soluble protein/protein ratio significantly $(P<0.001)$ decreased as a function of the increase in the thermal treatments. Similar results were found for buttermilks (Tab. I). The decrease in soluble protein contents with the heattreatment intensity corresponded to about $50 \%$ from low to high heat treatments in the creams, whereas it represented about $44 \%$ in buttermilks. Thermal denaturation of whey proteins in cream increased with the heat treatment (Fig. 1). Heat treatment induced changes in the nature of protein composition (whey proteins) [6].

In skimmed buttermilk prepared from raw cream, O'Connell and Fox [33] quantified $25( \pm 3.2) \%$ expressed in weight of soluble protein/protein. Consequently, in our study, a low heat treatment $\left(72{ }^{\circ} \mathrm{C}\right.$ for $30 \mathrm{~s}$ ) on milk, followed by a low heat treatment $\left(88^{\circ} \mathrm{C}\right.$ for $\left.30 \mathrm{~s}\right)$ on cream, induced a $55 \%$ soluble protein denaturation.

Table I shows that the contents of the major whey proteins, i.e. $\beta-\mathrm{Lg}$ and $\alpha-\mathrm{La}$, in the buttermilks decreased as a function of the increase in heat treatment intensity. 
Table I. Physicochemical compositions of the creams with three different levels of heat treatments applied and the respective buttermilks after butter production ${ }^{1}$.

\begin{tabular}{|c|c|c|c|c|c|}
\hline \multirow{2}{*}{$\begin{array}{l}\text { Cream } \\
\mathrm{pH}\end{array}$} & & Low heat & Medium heat & High heat & \multirow{2}{*}{$\begin{array}{c}\boldsymbol{P} \text {-value } \\
\text { NS }\end{array}$} \\
\hline & & $6.79^{\mathrm{a}} \pm 0.01$ & $6.77^{\mathrm{a}} \pm 0.02$ & $6.77^{\mathrm{a}} \pm 0.01$ & \\
\hline${ }^{\circ}$ Dornic & & $10.00^{\mathrm{a}} \pm 0.00$ & $10.00^{\mathrm{a}} \pm 0.00$ & $10.00^{\mathrm{a}} \pm 0.00$ & NS \\
\hline Dry matter & $\mathrm{g} \cdot \mathrm{kg}^{-1}$ & $453.77^{\mathrm{a}} \pm 27.55$ & $460.05^{\mathrm{a}} \pm 14.22$ & $474.46^{\mathrm{a}} \pm 12.25$ & NS \\
\hline Protein & $\mathrm{g} \cdot \mathrm{kg}^{-1}$ & $18.21^{\mathrm{a}} \pm 0.27$ & $17.46^{\mathrm{b}} \pm 0.34$ & $16.83^{\mathrm{c}} \pm 0.47$ & $* *$ \\
\hline Casein & $\mathrm{g} \cdot \mathrm{kg}^{-1}$ & $15.75^{\mathrm{a}} \pm 0.14$ & $15.72^{\mathrm{a}} \pm 0.39$ & $15.60^{\mathrm{a}} \pm 0.40$ & NS \\
\hline Soluble protein & $\mathrm{g} \cdot \mathrm{kg}^{-1}$ & $2.47^{\mathrm{a}} \pm 0.18$ & $1.74^{\mathrm{b}} \pm 0.10$ & $1.23^{c} \pm 0.17$ & $* * *$ \\
\hline Non protein nitrogen & $\mathrm{g} \cdot \mathrm{kg}^{-1}$ & $1.17^{\mathrm{a}} \pm 0.18$ & $1.06^{\mathrm{a}} \pm 0.05$ & $1.13^{\mathrm{a}} \pm 0.15$ & NS \\
\hline Casein/Protein & $\%$ & $86.46^{\mathrm{a}} \pm 0.79$ & $90.01^{\mathrm{b}} \pm 0.65$ & $92.42^{\mathrm{c}} \pm 0.92$ & $* * *$ \\
\hline Soluble protein/Protein & $\%$ & $13.54^{\mathrm{a}} \pm 0.79$ & $9.99^{\mathrm{b}} \pm 0.65$ & $7.28^{c} \pm 0.89$ & $* * *$ \\
\hline Protein/non Fat & $\mathrm{g} \cdot \mathrm{kg}^{-1}$ & $30.14^{\mathrm{a}} \pm 2.22$ & $30.47^{\mathrm{a}} \pm 1.69$ & $29.11^{\mathrm{a}} \pm 0.91$ & NS \\
\hline Fat & $\mathrm{g} \cdot \mathrm{kg}^{-1}$ & $393.38^{\mathrm{a}} \pm 38.46$ & $425.15^{\mathrm{a}} \pm 37.99$ & $421.86^{\mathrm{a}} \pm 13.82$ & NS \\
\hline Phospholipid & $\mathrm{g} \cdot \mathrm{kg}^{-1}$ & $10.27^{\mathrm{a}} \pm 1.04$ & $11.30^{\mathrm{a}} \pm 1.43$ & $12.44^{\mathrm{a}} \pm 3.82$ & NS \\
\hline Phospholipid/Fat & $\%$ & $2.64^{\mathrm{a}} \pm 0.47$ & $2.67^{\mathrm{a}} \pm 0.34$ & $3.07^{\mathrm{a}} \pm 0.93$ & NS \\
\hline \multicolumn{6}{|l|}{ Buttermilk } \\
\hline $\mathrm{pH}$ & & $6.75^{\mathrm{a}} \pm 0.02$ & $6.80^{\mathrm{a}} \pm 0.04$ & $6.79^{\mathrm{a}} \pm 0.08$ & NS \\
\hline${ }^{\circ}$ Dornic & & $15.33^{\mathrm{a}} \pm 0.52$ & $15.33^{\mathrm{a}} \pm 0.52$ & $14.67^{b} \pm 0.52$ & * \\
\hline Dry matter & $\mathrm{g} \cdot \mathrm{kg}^{-1}$ & $90.20^{\mathrm{a}} \pm 4.76$ & $91.59^{\mathrm{a}} \pm 2.54$ & $88.76^{\mathrm{a}} \pm 1.77$ & NS \\
\hline Protein & $\mathrm{g} \cdot \mathrm{kg}^{-1}$ & $29.13^{\mathrm{a}} \pm 1.26$ & $29.44^{\mathrm{a}} \pm 0.66$ & $27.77^{\mathrm{b}} \pm 0.77$ & * \\
\hline Casein & $\mathrm{g} \cdot \mathrm{kg}^{-1}$ & $25.90^{\mathrm{a}} \pm 1.10$ & $26.81^{\mathrm{a}} \pm 0.64$ & $25.96^{\mathrm{a}} \pm 0.64$ & NS \\
\hline Soluble protein & $\mathrm{g} \cdot \mathrm{kg}^{-1}$ & $3.24^{\mathrm{a}} \pm 0.16$ & $2.64^{\mathrm{b}} \pm 0.05$ & $1.81^{\mathrm{c}} \pm 0.15$ & $* * *$ \\
\hline Non protein nitrogen & $\mathrm{g} \cdot \mathrm{kg}^{-1}$ & $1.81^{\mathrm{a}} \pm 0.04$ & $1.63^{\mathrm{b}} \pm 0.12$ & $1.69^{\mathrm{b}} \pm 0.08$ & $* *$ \\
\hline Casein/Protein & $\%$ & $88.89^{\mathrm{a}} \pm 0.07$ & $91.04^{\mathrm{b}} \pm 0.19$ & $93.48^{c} \pm 0.39$ & $* * *$ \\
\hline Soluble protein/Protein & $\%$ & $11.11^{\mathrm{a}} \pm 0.07$ & $8.96^{\mathrm{b}} \pm 0.19$ & $6.52^{\mathrm{c}} \pm 0.39$ & $* * *$ \\
\hline Protein/non Fat & $\mathrm{g} \cdot \mathrm{kg}^{-1}$ & $29.29^{\mathrm{a}} \pm 1.26$ & $29.57^{\mathrm{a}} \pm 0.66$ & $27.91^{\mathrm{b}} \pm 0.77$ & $*$ \\
\hline Fat & $\mathrm{g} \cdot \mathrm{kg}^{-1}$ & $5.44^{\mathrm{a}} \pm 0.57$ & $4.49^{\mathrm{b}} \pm 0.62$ & $5.15^{\mathrm{ab}} \pm 0.95$ & * \\
\hline Phospholipid & $\mathrm{g} \cdot \mathrm{kg}^{-1}$ & $0.93^{\mathrm{a}} \pm 0.08$ & $0.82^{\mathrm{b}} \pm 0.04$ & $1.12^{c} \pm 0.03$ & $* * *$ \\
\hline Phospholipid/Fat & $\%$ & $17.25^{\mathrm{a}} \pm 2.09$ & $18.49^{\mathrm{a}} \pm 2.68$ & $22.57^{b} \pm 4.56$ & * \\
\hline Total Calcium & $\mathrm{g} \cdot \mathrm{kg}^{-1}$ & $0.99^{\mathrm{a}} \pm 0.14$ & $1.15^{\mathrm{b}} \pm 0.03$ & $0.97^{\mathrm{ab}} \pm 0.02$ & $* *$ \\
\hline$\beta-\mathrm{Lg}$ & $\mathrm{g} \cdot \mathrm{kg}^{-1}$ & $1.60^{\mathrm{a}} \pm 0.08$ & $0.71^{\mathrm{b}} \pm 0.10$ & $0.29^{c} \pm 0.13$ & $* *$ \\
\hline$\alpha-\mathrm{La}$ & $\mathrm{g} \cdot \mathrm{kg}^{-1}$ & $0.65^{\mathrm{a}} \pm 0.04$ & $0.54^{\mathrm{b}} \pm 0.02$ & $0.33^{\mathrm{b}} \pm 0.19$ & $*$ \\
\hline
\end{tabular}

${ }^{1}$ Mean $\pm \operatorname{sd}(n=3)$.

a,b,c Means in a row with different letters are significantly different at $P<0.05(*), P<0.01(* *)$ and $P<0.001$ (***).

NS: Not significantly different.

$\beta$-Lg: $\beta$-lactoglobulin; $\alpha$-Lac: $\alpha$-lactalbumin.

When $\beta$-Lg and $\alpha$-La are denatured in whole milk, it goes through four possible processes: (i) it denatures and becomes unsoluble; (ii) it can react with another denatured serum protein; (iii) it can react with micellar $\kappa$-casein; and (iv) it can adsorb on, or bind to protein on the MFGM. Dalgleish and Banks [7] found that the last of the four possibilities is favoured. They concluded that MFGM proteins react rapidly with serum proteins, or the latter adsorb rapidly onto the fat surface. Ye et al. [53] indicated that $\beta-\mathrm{Lg}$ and $\alpha-\mathrm{La}$ contents in whole milk could be associated with the MFGM via sulphydryl-disulphide interchanges with the MFGM proteins. 


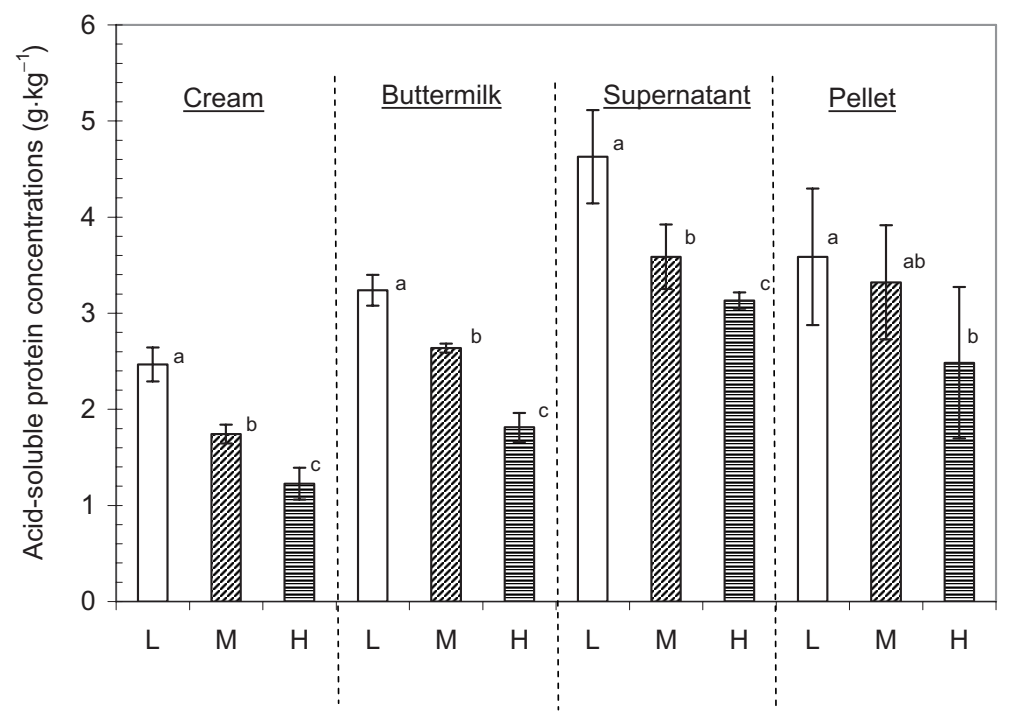

Figure 1. Acid-soluble protein contents (Non-Casein Nitrogen - Non-Protein Nitrogen) in cream, buttermilk, supernatant and pellet fractions after different cream heat treatments: low (L), medium (M) and high (H).

a,b,c Mean values of three replicates with no common superscript letter differed $(P<0.05)$.

The amounts of $\beta$ - $\mathrm{Lg}$ and $\alpha$-La that were associated increased with the temperature up to $80{ }^{\circ} \mathrm{C}$ for $10 \mathrm{~min}$. This increase reaches a plateau level of approximately $1.0 \mathrm{mg} \cdot \mathrm{g}^{-1}$ fat for $\beta-\mathrm{Lg}(\sim 1 \%$ of the total $\beta$ - $\mathrm{Lg}$ in milk) and $0.2 \mathrm{mg} \cdot \mathrm{g}^{-1}$ fat for $\alpha$-La.

The concentration of calcium in buttermilks was significantly $(P<0.01)$ different between the samples (Tab. I), but was in the range of the calcium concentration in cow's milk (1.04-1.28 g. $\left.\mathrm{kg}^{-1}\right)$ [15]. It is known that about two-thirds of the calcium present in milk is bound to the casein micelles, thus the differences observed between calcium contents may be related to the casein/protein ratio. Ramachandra Rao [36] and O'Connell and Fox [33] reported that total calcium concentration in buttermilk $\left(0.84 \mathrm{~g} \cdot \mathrm{kg}^{-1}\right.$ and $0.948 \mathrm{~g} \cdot \mathrm{kg}^{-1}$, respectively) is lower than in skimmed milk (1.04 $\mathrm{g} \cdot \mathrm{kg}^{-1}$ and $0.119 \mathrm{~g} \cdot \mathrm{kg}^{-1}$, respectively). However, in these studies the authors reported that buttermilk protein contents $\left(30 \mathrm{~g} \cdot \mathrm{kg}^{-1}\right.$ and
$31 \mathrm{~g} \cdot \mathrm{kg}^{-1}$, respectively) were lower than in skimmed milk (34 $\mathrm{g} \cdot \mathrm{kg}^{-1}$ and $33 \mathrm{~g} \cdot \mathrm{kg}^{-1}$, respectively).

Table I shows that the concentration of fat in the creams was not significantly different whatever the heat treatment applied. The cream fat contents determined by the UCLAB dairy company (Landerneau, France) with Rose Gottlieb extraction [13] were not significantly different (data not shown). The amount of phospholipids in the creams was not significantly different as a function of heat treatment (10.27$\left.12.44 \mathrm{~g} \cdot \mathrm{kg}^{-1}\right)$, nor the phospholipid/fat ratio (2.64-3.07\%) (Tab. I). According to different authors [26,32], in cow's milk, PL make up about $0.5-1 \%$ in weight of total lipids.

Significant $(P<0.05)$ differences in the fat content were evidenced in buttermilk, with B-Medium $\leqslant$ B-High $\leqslant$ B-Low and B-Medium < B-Low (Tab. I). The amount of phospholipids in buttermilks was significantly $(P<0.001)$ different, 
Table II. Physicochemical composition of the supernatant and pellet fractions from buttermilks after rennet coagulation and centrifugation ${ }^{1}$.

\begin{tabular}{|c|c|c|c|c|c|}
\hline Supernatant & & Low heat & Medium heat & High heat & $P$-value \\
\hline $\mathrm{pH}$ & & $6.61^{\mathrm{a}} \pm 0.05$ & $6.79^{b} \pm 0.03$ & $6.72^{c} \pm 0.03$ & $* * *$ \\
\hline${ }^{\circ}$ Dornic & & $10.17^{\mathrm{a}} \pm 0.41$ & $11.00^{\mathrm{a}} \pm 0.89$ & $12.33^{\mathrm{b}} \pm 1.37$ & * \\
\hline Dry matter & $\mathrm{g} \cdot \mathrm{kg}^{-1}$ & $64.83^{\mathrm{a}} \pm 0.03$ & $72.37^{\mathrm{b}} \pm 1.59$ & $79.90^{c} \pm 3.37$ & $* * *$ \\
\hline Protein & $\mathrm{g} \cdot \mathrm{kg}^{-1}$ & $6.56^{\mathrm{a}} \pm 1.37$ & $10.29^{\mathrm{b}} \pm 0.52$ & $17.56^{\mathrm{c}} \pm 3.33$ & $* *$ \\
\hline Casein & $\mathrm{g} \cdot \mathrm{kg}^{-1}$ & $1.93^{\mathrm{a}} \pm 1.61$ & $6.70^{\mathrm{b}} \pm 0.71$ & $14.43^{c} \pm 3.41$ & ** \\
\hline Soluble protein & $\mathrm{g} \cdot \mathrm{kg}^{-1}$ & $4.63^{\mathrm{a}} \pm 0.49$ & $3.59^{\mathrm{ab}} \pm 0.34$ & $3.13^{\mathrm{b}} \pm 0.08$ & $* * *$ \\
\hline Non protein nitrogen & $\mathrm{g} \cdot \mathrm{kg}^{-1}$ & $2.38^{\mathrm{a}} \pm 0.18$ & $2.29^{\mathrm{ab}} \pm 0.25$ & $2.08^{b} \pm 0.11$ & * \\
\hline Casein/Protein & $\%$ & $26.69^{\mathrm{a}} \pm 17.08$ & $65.02^{\mathrm{b}} \pm 4.32$ & $81.51^{\mathrm{c}} \pm 4.22$ & * \\
\hline Soluble protein/Protein & $\%$ & $73.31^{\mathrm{a}} \pm 17.08$ & $34.98^{\mathrm{b}} \pm 4.32$ & $18.49^{c} \pm 4.22$ & * \\
\hline Total Calcium & $\mathrm{g} \cdot \mathrm{kg}^{-1}$ & $0.42^{\mathrm{a}} \pm 0.03$ & $0.56^{\mathrm{b}} \pm 0.02$ & $0.73^{\mathrm{c}} \pm 0.02$ & $* * *$ \\
\hline Fat & $\mathrm{g} \cdot \mathrm{kg}^{-1}$ & $5.15^{\mathrm{a}} \pm 0.79$ & $4.75^{\mathrm{a}} \pm 0.63$ & $5.26^{\mathrm{a}} \pm 0.78$ & NS \\
\hline Phospholipid & $\mathrm{g} \cdot \mathrm{kg}^{-1}$ & $0.99^{\mathrm{ab}} \pm 0.12$ & $0.93^{\mathrm{a}} \pm 0.13$ & $1.08^{b} \pm 0.06$ & $*$ \\
\hline Phospholipid/Fat & $\%$ & $20.53^{\mathrm{a}} \pm 3.98$ & $19.87^{\mathrm{a}} \pm 3.51$ & $21.27^{\mathrm{a}} \pm 3.47$ & NS \\
\hline \multicolumn{6}{|l|}{ Pellet } \\
\hline $\mathrm{pH}$ & & $6.57^{\mathrm{a}} \pm 0.13$ & $6.78^{\mathrm{b}} \pm 0.02$ & $6.75^{\mathrm{b}} \pm 0.06$ & $* * *$ \\
\hline Dry matter & $\mathrm{g} \cdot \mathrm{kg}^{-1}$ & $250.27^{\mathrm{a}} \pm 6.89$ & $218.84^{\mathrm{b}} \pm 3.72$ & $214.29^{\mathrm{b}} \pm 6.59$ & $* * *$ \\
\hline Protein & $\mathrm{g} \cdot \mathrm{kg}^{-1}$ & $179.62^{\mathrm{a}} \pm 12.34$ & $147.31^{\mathrm{b}} \pm 4.83$ & $147.36^{\mathrm{b}} \pm 8.46$ & $* * *$ \\
\hline Casein & $\mathrm{g} \cdot \mathrm{kg}^{-1}$ & $176.04^{\mathrm{a}} \pm 12.79$ & $143.86^{a} \pm 5.23$ & $144.98^{\mathrm{b}} \pm 8.59$ & $* * *$ \\
\hline Soluble protein & $\mathrm{g} \cdot \mathrm{kg}^{-1}$ & $3.59^{\mathrm{a}} \pm 0.71$ & $3.32^{\mathrm{ab}} \pm 0.59$ & $2.49^{b} \pm 0.79$ & * \\
\hline Non protein nitrogen & $\mathrm{g} \cdot \mathrm{kg}^{-1}$ & $1.95^{\mathrm{a}} \pm 0.32$ & $2.01^{\mathrm{a}} \pm 0.03$ & $2.57^{\mathrm{b}} \pm 0.42$ & $* *$ \\
\hline Casein/Protein & $\%$ & $97.98^{\mathrm{a}} \pm 0.50$ & $97.65^{\mathrm{a}} \pm 0.55$ & $98.37^{\mathrm{a}} \pm 0.65$ & NS \\
\hline Soluble protein/Protein & $\%$ & $2.02^{\mathrm{ab}} \pm 0.50$ & $2.35^{\mathrm{a}} \pm 0.55$ & $1.63^{\mathrm{b}} \pm 0.65$ & $*$ \\
\hline Total Calcium & $\mathrm{g} \cdot \mathrm{kg}^{-1}$ & $5.62^{\mathrm{a}} \pm 0.34$ & $5.23^{\mathrm{b}} \pm 0.14$ & $4.78^{\mathrm{b}} \pm 0.28$ & * \\
\hline Weight $\mathrm{g} / 100 \mathrm{~g}$ buttermilk & & $12.98^{\mathrm{a}} \pm 0.65$ & $14.27^{\mathrm{a}} \pm 1.61$ & $7.67^{\mathrm{b}} \pm 3.93$ & * \\
\hline
\end{tabular}

${ }^{1}$ Mean $\pm \operatorname{sd}(n=3)$.

a,b,c Means in a row with different letters are significantly different at $P<0.05(*), P<0.01$ (**) and $P<0.001(* * *)$.

NS: Not significantly different.

with B-Medium < B-Low < B-High in their increasing order of concentration. The different orders obtained for fat and phospholipids may be explained by standard deviation of content measurements. The current contents of phospholipids in buttermilks (Tab. I) were in agreement with other authors' observations $[5,37,45]$. The phospholipid/fat ratio showed significant $(P<0.05)$ differences between the buttermilks, with B-Low < B-Medium < B-High (Tab. I). This result clearly shows that the heat treatment intensity applied to the creams affected the phospholipid/fat ratio, with an increase when the intensity of the heat treatment was higher. These differences in the composition of fat reported for buttermilk resulted from a different behaviour of the creams during churning, as a function of the properties of milk fat globules after the heat treatment. In comparison with the creams, the phospholipid/fat ratio in the buttermilks increased by a factor of about 7 . During the mechanical treatment applied at low temperature to the partially crystallised fat globules during butter-making, the MFGM is disrupted and the phospholipids, which are polar lipids, are found in the buttermilk fraction. Indeed, other authors reported 
that heat treatments applied to milk can induce desorption of proteins and lipids from the MFGM $[18,53,54]$. We can put forth the assumption that heat treatments of cream may modify the MFGM properties, either desorption of phospholipids or ability for phase inversion during cream churning. A higher stability of smaller fat globules towards phase inversion induced by heat treatment may lead to an increase in the number of these small fat globules in buttermilks. Since small fat globules contain a higher phospholipid/fat content, this may explain the higher phospholipid/fat ratio measured in high heat-treated buttermilks. The mechanisms involved in the increased stability of smaller globules after heating need further investigation.

\subsection{Compositions of the supernatant and pellet fractions: comparison}

The average $\mathrm{pH}$ of the supernatant fractions was equivalent to that of the pellet fraction (Tab. II). The protein contents of the supernatant fraction were lower than those of buttermilk and increased significantly $(P<0.01)$ with the heat treatment intensity applied to the creams. This is obvious, because the rennet treatment insolubilises part of the proteins from buttermilk into the insoluble pellet fraction. Proteins were more or less coagulated by rennet and were recovered in the pellet fraction after centrifugation.

From a technical point of view, the average protein contents of cheese wheys vary from $6 \mathrm{~g} \cdot \mathrm{kg}^{-1}$ for fresh cheeses to

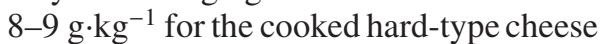
such as Emmental [30]. This leads to a protein recovery coefficient in the curd of from $72-74 \%$ (Grana, Emmental) to more than $82 \%$ in fresh cheeses. The protein concentrations in the supernatant fraction from buttermilk obtained from high preheated cream were much higher than those usually obtained in cheese technology. Thus, protein recovery coefficients in pellets decreased with the intensity of the heat treatments from $80 \%$ to $71 \%$ and to $41 \%$ for low, medium and high heat, respectively.

We deduced from our work that the protein losses in the supernatant fraction obtained after the B-High rennet coagulation and centrifugation were too high. This was due to the fact that heat treatment applied to the creams degraded the rennet ability of buttermilks, due to the well-known association of denatured whey proteins with $\kappa$-casein that impedes the rennet coagulation.

After coagulation and centrifugation, total lipids from buttermilk were found in the supernatant fraction. The centrifuged coagulum did not contain fat (results not shown). The coagulum after centrifugation, whatever the heat treatment, did not retain lipid particles (small fat globules, PL vesicles or MFGM fragments) in the casein network. It has been reported that native MFGM do not interact with casein during rennet gel formation [49], nor small fat globules with native MFGM [28]. On the other hand, fat globules covered with native whey proteins like $\beta$-Lg interact with the protein network and increase the viscoelactic properties of the gel [25]. Moreover, the centrifugal separation could have skimmed the rennet gel. Under the centrifugal force action, the buttermilk fat may have been dragged into the upper soluble fraction. This mechanical separation was not promoted by fat rising to the surface before coagulation because inactivated agglutinin cannot induce creaming [2].

\subsection{Determination of the particle size distribution in the creams, the buttermilks and the supernatant fractions}

The particle size distribution was characterised in the creams when they had just arrived in the laboratory (Fig. 2). The particle size distribution in the cream with 


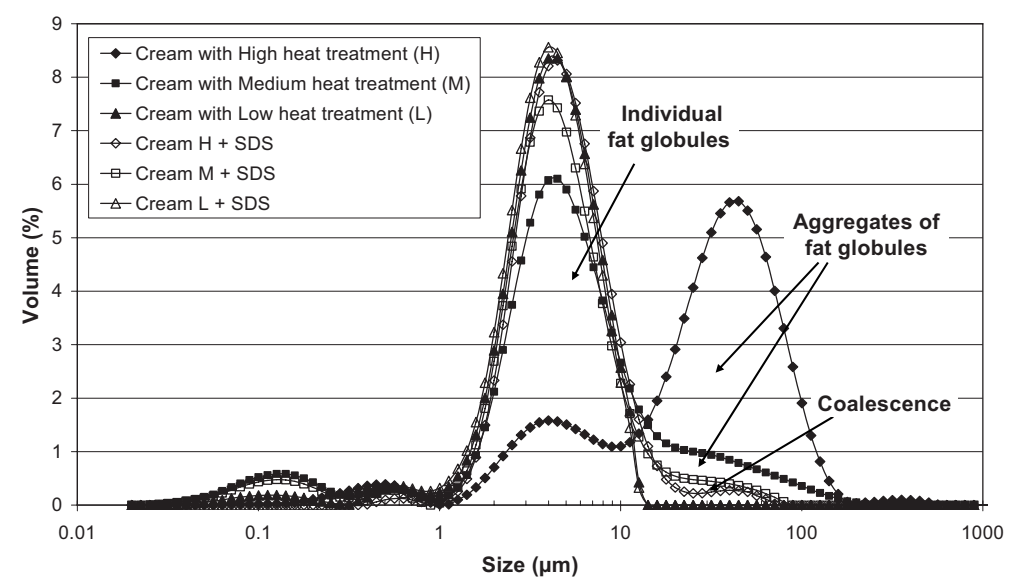

Figure 2. Particle size distributions recorded for the creams with low heat treatment $(\mathrm{L})$, medium heat treatment $(\mathrm{M})$ and high heat treatment $(\mathrm{H})$, using laser light scattering. The creams were dispersed in water in the presence of sodium dodecyl sulphate (SDS 1\%) and EDTA to dissociate the aggregates of fat globules and casein micelles, respectively. The fat globule size distribution in cream with low heat treatment is presented for comparison.

high heat treatment ranged from $0.02 \mu \mathrm{m}$ to $200 \mu \mathrm{m}$, with 3 peaks centred at about $0.5 \mu \mathrm{m}, 4 \mu \mathrm{m}$ and $45 \mu \mathrm{m}$. The addition of SDS and EDTA highly decreased the peak at about $45 \mu \mathrm{m}$, meaning that it corresponded to aggregates of fat globules. This peak of fat aggregates appeared with the highest heat treatment. The dissociation of fat globule aggregates with SDS 1\% allowed the measurement of the individual fat globule diameter, which ranged from 0.4 to $70 \mu \mathrm{m}$ with an average modal diameter of $4.48( \pm 0.12) \mu \mathrm{m}$. Figure 2 also shows that a small proportion of fat globules were even aggregated in the medium heat-treated creams. The addition of SDS did not change the size distribution of milk fat globules in the low heat-treated cream, as they were well individualised. Thus, no aggregates of fat globules were present in the creams with low heat treatment. The fat globule size distribution ranged from about $0.03 \mu \mathrm{m}$ to $13 \mu \mathrm{m}$, with an average modal diameter of $4.42( \pm 0.08) \mu \mathrm{m}$. Some larger fat globules, i.e. with diameters $>20 \mu \mathrm{m}$ in the presence of SDS, were recorded in the creams with medium and high heat treatments (Fig. 2). Compared with the size distribution of milk fat globules in raw milk [24], these fat globules may result from the fusion of smaller globules to form larger ones, due to coalescence.

The aggregation of fat globules may explain the higher viscosity of the high heat-treated creams compared with low heat-treated creams, as observed in the industrial maturation tank before churning (data not shown). Studies showed that after the heat treatment of milk, whey proteins (mainly $\beta-\mathrm{Lg}$ and $\alpha$-La) and caseins (mainly $\kappa$-casein) adsorb on the MFGM surface [54]. However, controversy persists about explanations concerning interaction mechanisms. Different authors think that these protein interactions between MFGM and milk proteins involve disulphide bridges [7, 21]. Houlihan et al. $[17,18]$ consider that the complex formed by $\beta$-Lg and $\kappa$-casein during heat treatment may displace the polypeptides from the MFGM during heating. All these authors agree that heat treatments modify the composition of MFGM and 


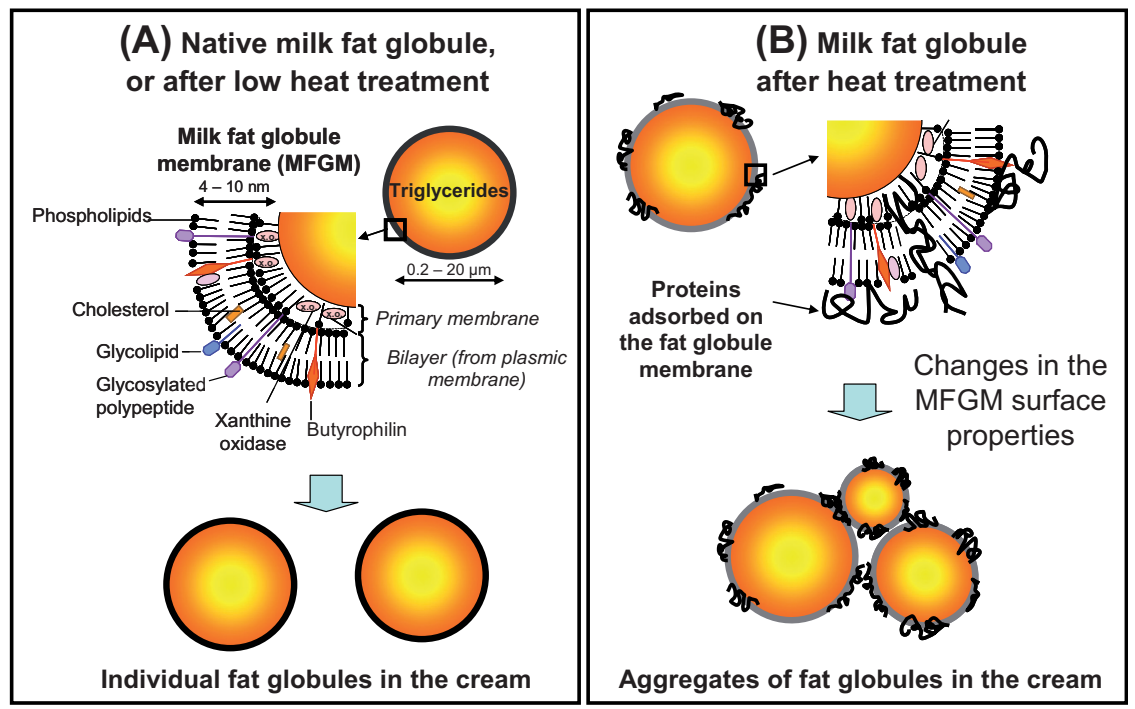

Figure 3. Changes in the MFGM composition as a function of the thermal treatment applied to the cream, and the consequences observed on their aggregation determined using laser light scattering measurements. Schematic representation of the milk fat globule membrane composition (A) in raw milk or after low heat treatment and (B) after high heat treatment, inducing the aggregation of fat globules.

their surface properties. Figure 3 shows a schematic representation of the milk fat globule surface in raw milk or after a low heat treatment which does not involve any modification of membrane structure or composition (Fig. 3A) and after a severe heat treatment with a MFGM modified by the adsorption of aqueous phase proteins, mainly whey proteins (Fig. 3B). These modifications of the MFGM composition, consecutive to a heat treatment, involved changes in interfacial properties which might result in the aggregation of fat globules (Fig. 2).

Figure 4A shows the size distribution of particles dispersed in the buttermilks resulting from the creams with low, medium and high heat treatments. The parameters extracted from particle size distributions are presented in Table III. After dispersion of the buttermilks in water, the major peak recorded from 0.02 to $0.4 \mu \mathrm{m}$ and centred at $130 \mathrm{~nm}$ corresponds to the size distribution of the casein micelles and other particles. In skimmed buttermilk, O'Connell and Fox [33] reported a casein micelle size of $206( \pm 31) \mathrm{nm}$. The dissociation of casein micelles performed by the addition of EDTA permitted the recording of the size of the other particles present in buttermilks. The peak ranging from 0.02 to $0.4 \mu \mathrm{m}$ contained casein micelles mixed with other constituents. The smallest particles observed in the presence of EDTA, with $d<0.4 \mu \mathrm{m}$, may correspond to fat globules of very small sizes (heart of triglycerides + membrane), vesicles formed by MFGM fragments mainly composed of PL and/or protein aggregates formed during heat treatments (whey protein or micelle complexes of casein-whey protein) (Fig. 4B). Recent work has characterised the structures formed through the release of lipid membrane material from fat globules by cryogenic transmission electron microscopy [50]. In buttermilk, 

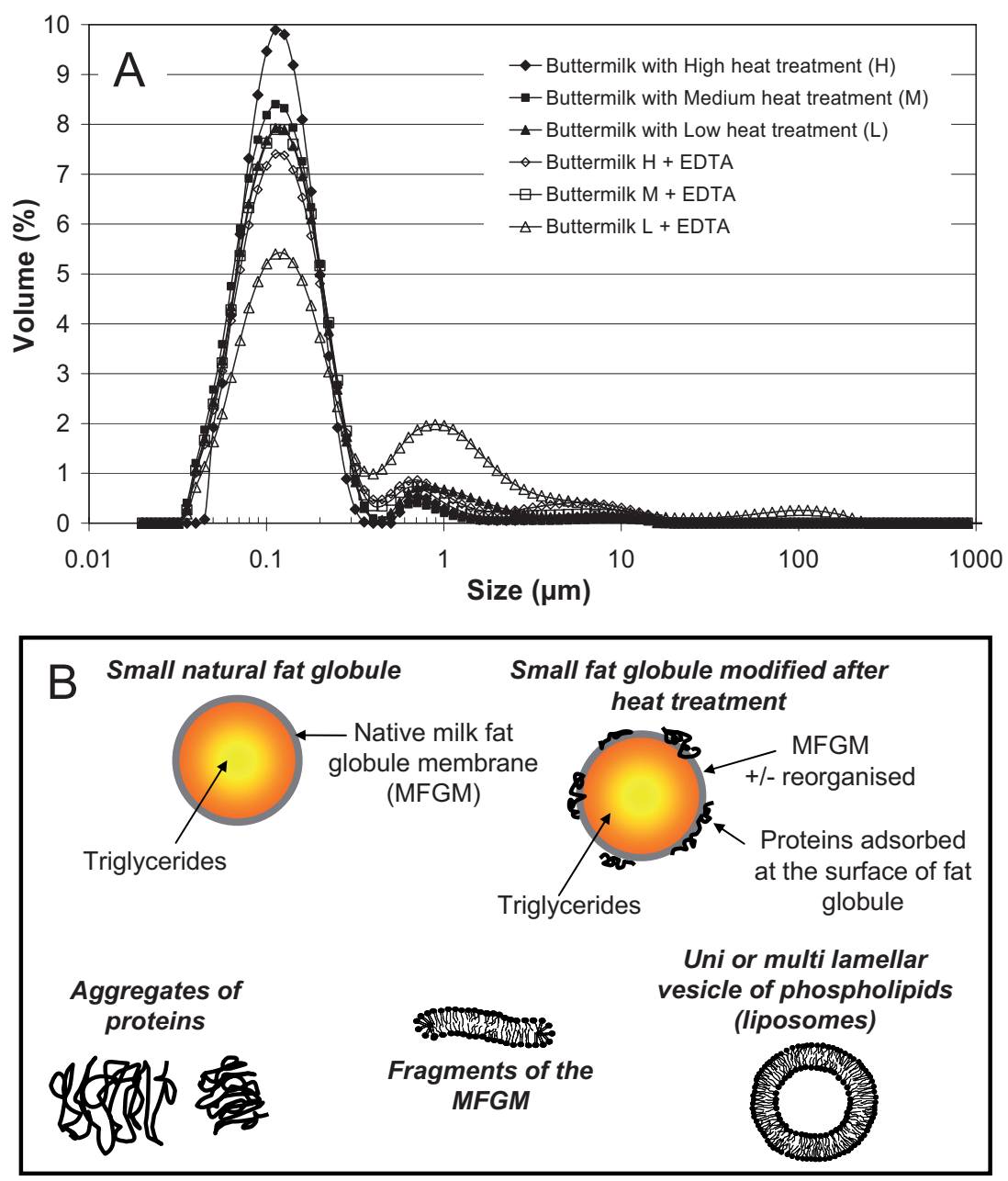

Figure 4. Particles dispersed in buttermilks. (A) Particle size distributions in buttermilks from 3 creams churned after low heat treatment $(\mathrm{L})$, medium heat treatment $(\mathrm{M})$ and high heat treatment $(\mathrm{H})$ determined using laser light scattering. Each buttermilk was dispersed in water in the presence of EDTA to dissociate the casein micelles. (B) Schematic representation of the particles possibly present in the buttermilks, the size of which is centred on $130 \mathrm{~nm}$ (not to scale).

spherical and slightly deformed vesicles are visible and could be formed from membrane components, mainly PL, after MFGM rupture during churning.

The particles, whose size ranged between approximately 0.4 and $20 \mu \mathrm{m}$, might correspond to residual fat globules. The larger particles, with a size higher than
$0.4 \mu \mathrm{m}$, represented a higher volume in the low heat-treated buttermilk compared with the medium and the high heat-treated buttermilk. The particles with sizes higher than $20 \mu \mathrm{m}$ may correspond to the fusion of smaller-sized fat globules through a coalescence mechanism. A schematic view of buttermilk particle composition 
Table III. Size distribution parameters for buttermilks from creams characterised by different levels of heat treatments and respective soluble fractions after buttermilk rennet coagulation followed by centrifugation. The parameters were extracted from the particle size distribution recorded using laser light scattering.

\begin{tabular}{lcccc}
\hline Samples $^{1}$ & \multicolumn{4}{c}{ Size distribution parameters } \\
\cline { 2 - 5 } & $\begin{array}{c}\mathrm{D}_{\text {mod }} \\
(\mu \mathrm{m})\end{array}$ & $\begin{array}{c}\mathrm{D}_{43} \\
(\mu \mathrm{m})\end{array}$ & $\begin{array}{c}\mathrm{D}_{\mathrm{v} 0.5} \\
(\mu \mathrm{m})\end{array}$ & $\begin{array}{c}\mathrm{D}_{\mathrm{v} 0.9} \\
(\mu \mathrm{m})\end{array}$ \\
\hline Buttermilk & & & & \\
$\quad$ - Low HT & $0.13 \pm 0.01$ & $0.48 \pm 0.18$ & $0.17 \pm 0.03$ & $1.60 \pm 1.30$ \\
$\quad$ - Medium HT & $0.13 \pm 0.01$ & $0.40 \pm 0.17$ & $0.14 \pm 0.01$ & $0.66 \pm 0.31$ \\
$\quad$ - High HT & $0.13 \pm 0.01$ & $0.54 \pm 0.17$ & $0.14 \pm 0.01$ & $0.66 \pm 0.34$ \\
Supernatant fraction & & & & \\
$\quad$ - Low HT & $0.13 \pm 0.01$ & $1.00 \pm 0.41$ & $0.15 \pm 0.01$ & $1.02 \pm 0.34$ \\
- Medium HT & $0.13 \pm 0.01$ & $0.34 \pm 0.11$ & $0.14 \pm 0.01$ & $0.43 \pm 0.09$ \\
- High HT & $0.13 \pm 0.01$ & $0.36 \pm 0.01$ & $0.13 \pm 0.01$ & $0.44 \pm 0.18$ \\
\hline
\end{tabular}

${ }^{1}$ HT: Heat treatment.

${ }^{2} \mathrm{D}_{\text {mod }}=$ modal diameter of particles; $\mathrm{D}_{43}=$ volume mean diameter of particles; $\mathrm{D}_{\mathrm{v} 0.5}=$ diameter below which lie $50 \%$ of particles, in volume; $\mathrm{D}_{\mathrm{v} 0.9}=$ diameter below which lie $90 \%$ of particles, in volume.

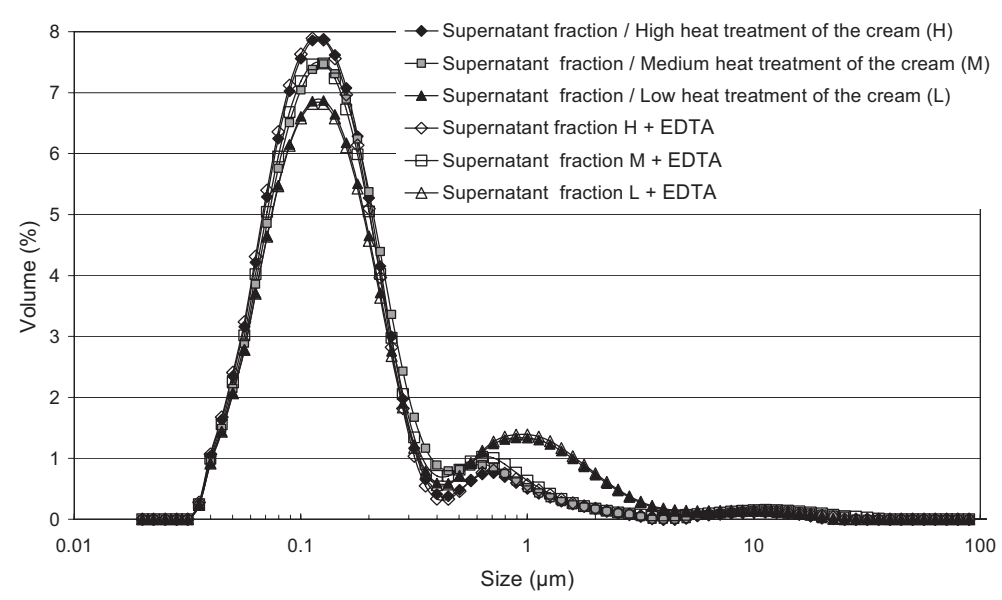

Figure 5. Particle size distribution in the supernatant fractions resulting from the heat-treated creams: low heat treatment $(\mathrm{L})$, medium heat treatment $(\mathrm{M})$, high heat treatment $(\mathrm{H})$. The size of the particles was determined using laser light scattering after dispersion of the buttermilks in water in the presence of EDTA to dissociate the casein micelles.

and structure corresponding to the peak centred on $130 \mathrm{~nm}$ is presented in Figure 4B. The particles present in buttermilk may correspond to casein micelles, protein aggregates, residual small-sized fat globules and PL vesicles.

The size distributions of the particles present in the buttermilk supernatant frac- tion are presented in Figure 5. The profiles were similar in the presence or absence of EDTA, although high heat treatment led to an increase in protein contents in the soluble phase rich in casein fines due to a lower rennetability. The casein fines were not EDTA-sensitive. As for buttermilks, the major peak ranges from 0.02 to $0.4 \mu \mathrm{m}$, 
with a maximum at $130 \mathrm{~nm}$. Larger particles, with $0.4 \mu \mathrm{m}>\mathrm{d} \geq 20 \mu \mathrm{m}$ were also characterised in the soluble fractions. They may correspond to residual milk fat globules.

\section{CONCLUSION}

Increasing the knowledge of the physicochemical properties of buttermilks, as a function of the thermal treatment applied to creams, will allow the improvement of their functional properties and the valorisation of their constituents. As already evidenced in milk, increasing the intensity of the heat treatment applied to cream led to whey protein insolubilisation via its denaturation in buttermilks. This increased protein denaturation decreased the buttermilk rennetability. Aggregation of high heat-treated fat globules was evidenced, which could explain variations in viscosity and stability of sweet, industrial creams before churning. The amount of phospholipid in the fat fraction of buttermilks increased with the intensity of cream heat treatment. The nature of the main particles dispersed in buttermilk, with a size of about $130 \mathrm{~nm}$, has been suggested and is under study.

Acknowledgements: The authors would like to thank S. Keromnes (UCLAB, Landerneau, France) for providing cream and buttermilk samples. We thank E. Beaucher and V. BriardBion for analytical assistance. F. Rousseau is acknowledged for her help with laser light scattering measurements.

\section{REFERENCES}

[1] AFNOR, Détermination de l'acidité, Lait, Norme NF V 04-206, AFNOR, 1969.

[2] Alais C., Les lipides, la matière grasse, la crème, in: Sefaic (Eds.), Science du Lait: Principes des Techniques Laitières, Paris, 1984, pp. 61-106.
[3] Brulé G., Maubois J.L., Fauquant J., Étude de la teneur en éléments minéraux des produits obtenus lors de l'ultrafiltration du lait sur membrane, Lait 54 (1974) 600-615.

[4] Centre National Interprofessionnel de l'Économie Laitière, L'Économie Laitière en Chiffres, in: Centre National Interprofessionnel de l'Économie Laitière, Paris, France, 2007.

[5] Christie W.W., Noble R.C., Davies G., Phospholipids in milk and dairy products, $\mathrm{J}$. Soc. Dairy Technol. 40 (1987) 10-12.

[6] Dalgleish D.G., Denaturation and aggregation of serum proteins and caseins in heated milk, J. Agric. Food Chem. 38 (1990) 19951999.

[7] Dalgleish D.G., Banks J.M., The formation of complexes between serum proteins and fat globules during heating of whole milk, Milchwissenschaft 46 (1991) 75-78.

[8] Danthine S., Blecker C., Paquot M., Innocente N., Deroanne C., Progress in milk fat globule membrane research: a review, Lait 80 (2000) 209-222.

[9] Elling J.L., Duncan S.E., Physical properties of $20 \%$ milk fat reformulated creams manufactured from cholesterol-reduced butteroil, J. Food Sci. 61 (1996) 375-378.

[10] FIL/IDF, Fromages et fromages fondus, détermination de la teneur en phosphore total (méthode photométrique), standard 33C, Int. Dairy Fed. Brussels, Belgium, 1987.

[11] FIL/IDF, Lait, crème et lait concentré non sucré, détermination de la matière sèche, standard 21B, Int. Dairy Fed. Brussels, Belgium, 1987.

[12] FIL/IDF, Détermination de la teneur en azote, standard 20B, Int. Dairy Fed. Brussels, Belgium, 1993.

[13] FIL/IDF, Détermination de la teneur en matière grasse, Lait, Méthode gravimétrique, Standard 1D:1996, Int. Dairy Fed. Brussels, Belgium FIL/IDF, 1996.

[14] FIL/IDF, Lait et produits laitiers, détermination de la teneur en matière grasse, standard 152A, Int. Dairy Fed. Brussels, Belgium, 1997.

[15] Gaucheron F., The minerals of milk, Reprod. Nutr. Dev. 45 (2005) 473-483.

[16] Gripon J.C., Desmazeaud M., Le Bars D., Bergère J.L., Étude du rôle des microorganismes et de leurs enzymes dans la maturation des fromages. II. Influence de la présure commerciale, Lait 55 (1975) 502-516. 
[17] Houlihan A.V., Goddard P.A., Kitchen B.J., Masters C.J., Changes in structure of the bovine milk fat globule membrane on heating whole milk, J. Dairy Res. 59 (1992) 321329.

[18] Houlihan A.V., Goddard P.A., Nottingham S.M., Kitchen J., Masters C.J., Interaction between the bovine milk fat globule membrane and skim milk components on heating whole milk, J. Dairy Res. 59 (1992) 187195.

[19] Jean K., Renan M., Famelart M.H., Guyomarc'h F., Structure and surface properties of the serum heat-induced protein aggregates isolated from heated skim milk, Int. Dairy J. 16 (2006) 303-315.

[20] Keogh M.K., Chemistry and Technology of Butter and Milk Fat Spreads, in: Fox P.F., McSweeney P.L.H. (Eds.), Advanced Dairy Chemistry - Volume 2 - Lipids, Springer Science - Business Media, New York, USA, 2006, pp. 333-375.

[21] Kim H.H.Y., Jimenes-Flores R., Heatinduced interactions between the proteins of milk fat globule membrane and skim milk, J. Dairy Sci. 78 (1995) 24-35.

[22] Kimenai M.P., Continuous butter manufacture - Nizo method, Int. Dairy Fed. 204 (1986) 13-14.

[23] Lemonier L.A., Dillehay D.L., Vespremi M.J., Abrams J., Brody E., Chmelz E.M., Sphingomyelin in the suppression of colon tumors: prevention versus intervention, Arch. Biochem. Biophys. 419 (2003) 129-138.

[24] Lopez C., Focus on the supramolecular structure of milk fat in dairy products, Reprod. Nutr. Dev. 42 (2005) 497-511.

[25] Lopez C., Dufour E., The composition of milk fat globule surface alters the structural characteristics of the coagulum, J. Colloid Interface Sci. 233 (2001) 241-249.

[26] MacGibbon A.K.H., Taylor M.W., Composition and Structure of Bovine Milk Lipids, in: Fox P.F., McSweeney P.L.H. (Eds.), Advanced Dairy Chemistry Volume 2 - Lipids, Springer Science Business Media, New York, USA, 2006, pp. 1-42.

[27] Mather I.H., A review and proposed nomenclature for major proteins of the milk-fat globule membrane, J. Dairy Sci. 83 (2000) 203-370.

[28] Michalski M.C., Milkfat globules: physicochemical properties as a function of size, Bull. IDF 389 (2004) 104-107.
[29] Michalski M.C., Briard V., Michel F., Optical parameters of milk fat globules for laser light scattering measurements, Lait 81 (2001) 787-796.

[30] Mietton B., Gaucheron F., Salaün-Michel F., Minéraux et transformations fromagères, in: Gaucheron F. (Ed.), Minéraux et Produits Laitiers, Tec \& Doc, Paris, France, 2004, pp. 472-563.

[31] Mistry V.V., Low fat cheese technology, Int. Dairy J. 11 (2001) 413-422.

[32] Mulder H., Walstra P., The milk fat globule, Centre for Agricultural Publishing and Documentation, Wageningen, The Netherlands, 1974.

[33] O'Connell J.E., Fox P.F., Heat stability of buttermilk, J. Dairy Sci. 83 (2000) 17281732.

[34] Poduval V.S., Mistry V.V., Manufacture of reduced fat mozzarella cheese using ultrafiltered sweet buttermilk and homogenized cream, J. Dairy Sci. 82 (1999) 1-9.

[35] Rajor R.B., Gupta S.K., Soft-serve ice cream from soybean and buttermilk. I. Method of manufacture, Ind. J. Dairy Sci. 35 (1982) 454-459.

[36] Ramachandra Rao H.G., Mechanisms of flux decline during ultrafiltration of dairy products and influence of $\mathrm{pH}$ on flux rates of whey and buttermilk, Desalination 144 (2002) 319-324.

[37] Rombaut R., Camp J.V., Dewettinck K., Analysis of phospho- and sphingolipids in dairy products by a new HPLC method, J. Dairy Sci. 88 (2005) 482-488.

[38] Rueda R., Maldonaldo J., Narbona E., Gil A., Neonatal dietary gangliosides, Early Human Develop. 53 (1998) S135-S147.

[39] Schmelz E.M., Dillehay D.L., Webb S.K., Reiter A., Adams J., Merril A.H.J.R., Sphingomyelin consumption suppresses aberrant colonic crypt foci and increases the proportion of adenomas versus adenocarcinomas in CF1 mice treated with 1,2-dimenthylhydrazine: implication for dietary sphingolipids and colon carcinogenesis, Cancer Res. 56 (1996) 4936-4941.

[40] Schmelz E.M., Merril A.H.J.R., Ceramides and ceramide metabolites in cell regulation: Evidence for dietary sphingolipids as inhibitors of colon carcinogenesis, Nutrition 14 (1998) 717-719.

[41] Singh H., Tokley R.P., Effects of preheat treatments and buttermilk addition on the seasonal variations in the heat stability of recombined evaporated milk and reconstituted concentrated milk, Aust. J. Dairy Technol. 45 (1990) 10-16. 
[42] Sodini I., Morin P., Olabi A., Jimenez-Flores R., Compositional and functional properties of buttermilk: A comparison between sweet, sour, and whey buttermilk, J. Dairy Sci. 89 (2006) 525-536.

[43] Spitsberg V.L., Invited review: Bovine milk fat globule membrane as a potential nutraceutical, J. Dairy Sci. 88 (2005) 22892294.

[44] Sprong R.C., Hulstein M.F.E., van der Meer R., Bovine milk fat components inhibit foodborne pathogens, Int. Dairy J. 12 (2002) 209-215.

[45] Surel O., Famelart M.H., Ability of ceramic membranes to reject lipids of dairy products, Aust. J. Dairy Technol. 50 (1995) 36-40.

[46] Théodet C., Gandemer G., Comparaison de cinq méthodes pour extraire les lipides du lactosérum et de ses dérivés, Lait 71 (1991) 41-54.

[47] Trachoo N., Mistry V.V., Application of ultrafiltered sweet buttermilk and sweet buttermilk powder in the manufacture of nonfat and low fat yogurts, J. Dairy Sci. 81 (1998) 3163-3171.

[48] Turcot S., St-Gelais D., Turgeon S.L., Affinage de fromages allégés de type Cheddar fabriqués à partir de laits enrichis en phospholipides, Lait 82 (2002) 209-223.
[49] Van Vliet T., Dentener-Kikkert A., Influence of the composition of the milk fat globule membrane on the rheological properties of acid milk gels, Neth. Milk Dairy J. 36 (1982) 261-265.

[50] Waninge R., Kalda E., Paulsson M., Nylander T., Bergenstahl B., Cryo-TEM of isolated milk fat globule membrane structures in cream, Phys. Chem. Chem. Phys. 6 (2004) 1518-1523.

[51] Wolff R.L., Castera-Rossignol A., Mise au point et évaluation d'une méthode d'extraction de la matière grasse de fromage de type emmental, Rev. Fr. Corps Gras 34 (1987) 123-132.

[52] Wolff R.L., Fabien R.J., Utilisation de l'isopropanol pour l'extraction de la matière grasse de produits laitiers et pour l'estérification subséquente des acides gras, Lait 69 (1989) 33-46.

[53] Ye A., Singh H., Oldfield D.J., Anema S., Kinetics of heat-induced association of $\beta$-lactoglobulin and $\alpha$-lactalbumin with milk fat globule membrane in whole milk, Int. Dairy J. 14 (2004) 389-398.

[54] Ye A., Singh H., Taylor M.W., Anema S., Interactions of whey proteins with milk fat globule membrane proteins during heat treatment of whole milk, Lait 84 (2004) 269-283. 